\title{
THE CAUSAL RELATIONSHIP BETWEEN SELECTED MACROECONOMIC VARIABLES AND STOCK RETURNS IN TURKEY ${ }^{1}$
}

\author{
Ahmet TIRYAKi² Levent ERDOĞAN² Reşat CEYLAN \\ Abstract \\ This study investigates the causal relationship between selected domestic and international \\ macroeconomic variables and the stock returns in Turkey by using ARDL methodology for the period of \\ 2003:1-2016:12. By taking S\&P500 and World Oil Price Index as exogenous control variables, the study \\ finds that the main determinants of Turkish stock returns are the changes in industrial production index, \\ consumer price index, current account to export ratio, real effective exchange rate, Standard \& Poor's \\ 500 Index, World Oil Price Index and the interest difference between Turkish Central Bank policy rate and \\ the Federal Funds Rate of the USA in the long-run. The signs of industrial production index , consumer \\ price index, current account to export ratio, real effective exchange rate, S\&P500 and World Oil Price \\ Index are statistically significant and positive and the sign of the interest difference between Turkish policy \\ rate and the FFR is negative. The test results also show that Turkish unemployment rate does not have \\ any effect on Turkish stock returns.
}

Keywords: ARDL, Cointegration, Stock Returns, Economic Activity, BIST, Turkey

JEL Classification: E44, F3, F47.

\section{TÜRKIYE'DE SEÇiLMiş MAKROEKONOMIK DEĞiŞKENLER ILE HISSE SENEDi GETiRILERI ARASINDAKI NEDENSELLiK iLIŞKisi}

öz

Bu çalışma aylık verilerden ve ARDL yaklaşımından yararlanarak 2003 ile 2016 yılları arasında seçilmiş makroekonomik değişkenlerle hisse senedi getirileri arasındaki nedensellik ilişkisini araştırmaktadır. S\&P500 ve dünya petrol fiyat endeksini dışsal kontrol değişkenleri olarak kullanarak, bu çalışmanın ampirik test sonuçları uzun dönemde hisse senedi getirilerinin temel belirleyicilerinin imalat sanayi endeksi, tüketici fiyat endeksi, cari işlemler hesabının ihracata oranı, reel efektif döviz kuru, TCMB politika faizi ile FFR farkından oluşan faiz oranları farkı, S\&P500 ve dünya petrol fiyat endeksi olduğunu ortaya koymaktadır. Ampirik test sonuçları, BIST hisse senedi getirileri ile tüketici fiyat endeksi, cari işlemler hesabının ihracata oranı, reel efektif döviz kuru, S\&P500 ve dünya petrol fiyat endeksi arasında istatistiksel olarak anlamlı ve pozitif, TCMB politika faizi ile FFR farkından oluşan faiz oranları farkı arasında ise istatistiksel olarak anlamlı ve negatif bir ilişki olduğunu ortaya koymaktadır. İşsizlik oranındaki değişmelerin hisse senedi getirilerine bir etkisi yoktur.

Anahtar Kelimeler: ARDL, Eşbütünleşme, Hisse Senedi Getirisi, Ekonomik Aktivite, BiST, Türkiye

JEL Kodu: E44, F3, F47.

\footnotetext{
${ }^{1}$ Draft version of this paper is presented at EconAnadolu2017, Anadolu International Conference in Economics May 11-13, 2017 held in Eskişehir/Turkey.

${ }^{2}$ Assoc.Prof. Anadolu University, AOF, Turkey, ahmettiryaki@anadolu.edu.tr

${ }^{3}$ Assoc.Prof. Anadolu University, IIBF, Turkey, lerdogan@anadolu.edu.tr
}

DOI: 10.18092/ulikidince.309275

Makalenin Geliş Tarihi (Recieved Date): 26/04/2017 Yayına Kabul Tarihi (Acceptance Date): 14/06/2017 


\section{Introduction and the Theoretical Background}

Economic theory suggests that stock prices should reflect investors' expectations about the future firm profits. In that sense, profits reflect the level of aggregate domestic and international economic activity. Economic theory implies that there should be two way causal relationship between macroeconomic activity and stock market prices. Macroeconomic variables have a significant impact on stock market performance and reversely, stock markets have a significant role on the economic growth. As it will be listed below, many previous studies have reported the effects of macroeconomic variables on stock prices in different countries.

This paper aims to investigate the short-run and long-run causal relationship between key domestic and international macroeconomic variables, including Industrial production index (IPI), Inflation (CPI), Current Account balance to export ratio (CAEX), Unemployment rate (UNEMP), Real effective exchange rate (RER), Interest rate difference (INTDIF) between Turkish central bank policy rate and the USA Federal Funds Rate (FFR), the Standard \& Poor's 500 Index (S\&P500), and the World oil price index (OILP) and stock market prices in Turkey, represented by the BIST100, BISTFIN, and BISTIND.

In the study, monthly data is used from 2003:1 to 2016:12, and different than previous studies the ARDL methodology is used for estimations. By taking S\&P500 and OILP as exogenous control variables and considering the long-run effects of macroeconomic variables on all three (3) stock indexes, the ARDL test results show that main determinants of Turkish stock returns are the changes in Turkish IPI, CPI, CAEX, RER, S\&P500, and OILP. The test results show that Turkish unemployment rate does not have any effect on Turkish stock returns.

In the study, benefiting from economic literature in general and the literature about the Turkish economic developments, it is assumed that the main domestic and international macroeconomic determinants of the Turkish stock returns are the IPI, CPI, CAEX, UNEMP, RER, S\&P500 and OILP. In order to represent macroeconomic activity in Turkey, monthly data of Industrial production index, inflation, current account balance to export ratio, and unemployment rate are used to see their effect on stock returns. Also, real effective exchange rate and interest rate difference are used. Interest rate difference between Turkish central bank policy rate and the USA Federal Funds Rate not only shows the stance of Turkish Central Bank, also measures the affect coming from the USA to Turkish economy and Turkish stock returns. Since Turkish economy is small in terms of effecting world interest rate and economic developments, the international monetary policy and real supply shocks effects 
should be considered. For that purpose the study uses, besides the FFR, S\&P500 and World Oil Price Index as exogenous control variables.

This study uses Turkey's Industrial Production Index, Unemployment rate, and Current Account balance to export ratio to gauge the effect of economic activity to stock returns. Economic theory suggests that stock prices should reflect investors' expectations about the future firm profits. In that sense, profits reflect the level of aggregate domestic and international economic activities. On theoretical grounds, the positive relationship between stock prices and Industrial Production Index is expected. This expectation is also supported by empirical studies of Chen et al. (1986), Fama (1990), Schwert (1990), Mahdavi and Sohrabian (1991), Abdullah and Hayworth (1993), Gallinger (1994) and Apergis (1998), among others. Further, Mahdavi and Sohrabian (1991), Dhakal et al. (1993) and Gallinger (1994) note that asymmetric causation runs from stock returns to real economic activity. The stock returns-real economic activity causal relationship can be discussed as follows. Firstly, there is a link from the effects of major stock fluctuations on consumption and investment and, thus, may lead to an increased output. Alternatively, output may affect stock prices through its impact on profitability, since increase in output may boost cash flow and hence enhance stock prices.

Another macroeconomic variable that has effect on stock prices is the changes in the price level. The relationship between price level changes and stock prices are represented by changes in Consumer Price Index. The CPI focuses on the price of goods and services traded among the firms. It also monitors price movements that reflect supply and demand in the real economy. Theoretically it is expected a negative or positive relationship between price level changes and stock prices/returns. Two channels can explain this negative relationship. First, according to the classical theory implications and to Fama (1981), such relations are induced by the negative inflation-real activity relationship and so, stock returns are positively related to real variables like investment expenditures and output. Second, increased inflation may enhance the nominal risk-free rate and thus the discount rate. The positive relationship, on the other side, is indicated by the Keynesian approach since there is positive relationship exist between macroeconomic activity and price level and hence there should be a positive relationship between activity and the stock returns.

The effects of inflation on stock prices are empirically controversial. Abdullah and Hayworth (1993) found a positive relation between stock returns and inflation. However, the negative stock return-inflation relationship is empirically reported by Fama (1981), Schwert (1981), Gultekin (1983), Geske and Roll (1983) and Mukherjee and Naka (1995), among others.

\section{Uluslararası Íktisadi ve İdari İncelemeler Dergisi}


As Özer (2015) indicates, the Turkish economy is both an input and foreign finance dependent economy. Economy traditionally gives current account deficits most of the times and these deficits are financed mostly with international capital flows. Its exports are also is depended on imports of intermediate goods such as imports of machinery and oil\&gas. Without importation of these products, production and hence the exports of country is hampered. The inclusion of CAEX ratio to the study is important to understand the effect of foreign trade balance on the Turkish stock returns.

Another variable which is included to the study is the Real effective exchange rate. Theoretically, change in exchange rate affects the global performances of the firms which will affect their share prices. According to Abdalla and Murinde, (1997), under floating exchange rate regime, the volatility of the exchange rate is greater and inevitably leads to exchange rate risks. There are many explanations for stock price-real exchange rate relationship. First of all, changes in exchange rates may affect the value of firms' portfolios and thus, firms' stock prices. Second, there exist a negative relationship between stock prices and the home currency. For example, if exports are important for a country, the exchange rate appreciation lowers its competitiveness and negatively affects domestic stock prices. Third, there could be an indirect link between stock prices and exchange rates due to the relationship between exchange rates and economic activity, and between economic activity and stock prices. Fourth, exchange rates may influence stock prices through interest rate effects. Finally, foreign exchange rates are important for investors deciding whether they should invest in the foreign exchange market or in the stock market. Choi (1995) examines the impact of fundamental economic variables on relative stock price indices between the US and Japan, and notes that the exchange rate is the most significant factor among the variables.

Changes in interest rates affect the cost of borrowing and also effects future profitability of the firms. For example, a fall in interest rates reduces the cost of borrowing and encourages firms for expansion with the expectation of generating future expected returns for the firm. Interest rate changes play an important role in stock price movements. Theoretically, it is expected that an increase in interest rates or interest rate difference between Turkish central bank policy rate and the FFR will have a negative impact on stock returns, since an increase in interest rates may raise financing costs, and then reduce future corporate profitability and stock prices. However, opposite to expectations, Mukherjee and Naka (1995) found a positive relation between Japanese stock prices and call money rates.

The S\&P500 is considered as the best representative of the USA equities market. The index includes 500 leading companies in leading industries of the U.S. economy. Also, the S\&P 500 captures the changes in the prices of the index components. 
Theoretically, a positive relationship is expected between S\&P500 and Turkish stock returns. Since the changes in S\&P500 signals the direction of the future economic activity and profitability of the firms of the USA and world economy, it also signals the same direction externality effect on Turkish economy. The World Oil Price Index is used to control real supply shocks on stock returns. Changes in the OILP effects the cost of production and also expected to affect stock returns negatively.

This paper is organized as follows: The literature survey includes both the surveys of International and Turkish stock market theoretical and empirical studies. Then the econometric methodology and data is discussed. Empirical findings and policy implications finalize the paper.

\section{Literature Review}

\subsection{International Literature Review}

Macroeconomic variables have a significant impact on stock market performance and reversely. Many studies have reported the effects of macroeconomic variables on stock prices in different countries. Numerous studies, such as Chen et al. (1986), Fama (1990), Abdullah and Hayworth (1993), Gallinger (1994) and Mukherjee and Naka (1995) showed that stock returns are positively related to real economic activity. Levine and Zervos (1998) implied that stock market development has positively impact long-run economic growth. Gjerde and Sættem (1999) investigate relationship for Norway by utilizing the multivariate vector autoregressive (VAR) approach and find that the stock market shows a delayed response to changes in domestic real activity, real interest rate changes affect both stock returns and inflation, and the stock market responds accurately to oil price changes.

Kwon and Shin (1999) investigate relationship for Korea by using co-integration test and Granger causality test from a vector error correction model (VECM) and find that stock market reflects macroeconomic variables. However, they found that the stock price indices are not a leading indicator for economic variables, which is inconsistent with the theoretical implications and previous findings that the stock market rationally signals changes in real activities.

Rousseau and Wachtel (2000) by using the GMM for 47 countries, found that liquid stock markets had a significant impact on economic growth. Nasseh and Strauss (2000) find support for a significant, long-run relationship between stock prices and domestic and international economic activity in six European economies. Naceur et al. (2007) found that saving, financial institutions, stock market liquidity and inflation are important determinants of stock market development. Ratanapakorna and Sharma (2007) investigated the long-term and short-term relationships between the US stock price index, represented by S\&P 500, and macroeconomic variables over the period 1975-1999. Test results show that the

\section{Uluslararası İktisadi ve İdari İncelemeler Dergisi}


stock prices are negatively related to the long-term interest rate, but positively related to the money supply, industrial production, inflation, the exchange rate and the short-term interest rate. Also they found, in the Granger causality sense, every macroeconomic variable causes the stock prices in the long-run but not in the shortrun. Vazakidis and Adamopoulos, (2009) investigated the causal relationship between stock market development and economic growth for France by using VECM and found that economic growth causes stock market development.

Humpe and Macmillan (2009) examine whether macroeconomic variables influence stock prices in the USA and Japan. By using co-integration analysis they find stock prices are positively related to industrial production and negatively related to both the consumer price index and the long-term interest rate. Abugri (2008) investigates the relationship for Latin American countries by using a six-variable vector autoregressive (VAR) model, he finds that the global factors are consistently significant in explaining returns in all the markets. Shahbaz, et al. (2008) by using Engle-Granger causality and ARDL tests investigate the relationship for Pakistan and found very strong relationship between stock market development and economic growth. There is bi-directional causality between stock market development and economic growth. However, for short-run, there exist only one-way causality, i.e., from stock market development to economic growth. Yartey (2010) by using panel data of 42 emerging countries for the period 1990 to 2004, found that income level, investment, banking sector development, capital flows and stock market liquidity are important indicators of stock market development. Pradhan et al. (2013) by testing for 16 Asian countries found the existence of bi-directional causal relationship between stock market development, inflation and economic growth.

Tripathy (2011) investigated the causal relationship for the Indian stock market by using Granger Causality test and presents evidence of bi-directional relationship between interest rate and stock market, exchange rate and stock market, international stock market and BSE volume, exchange rate and BSE volume. Results suggest that any change of exchange rate, interest rate and international market significantly influencing the stock market in the economy and vice-versa. The study also reported unidirectional causality running from international stock market to domestic stock market, interest rate, exchange rate and inflation rate indicating sizeable influence in the stock market movement. Singh, et al. (2011) attempt to examine the casual for Taiwan. Empirical results show that exchange rate and GDP affect returns of all portfolios, while inflation rate, exchange rate, and money supply were having negative relationship with returns for portfolios of big and medium companies. Kumar and Padhi (2012) investigates the relationship between the Indian stock market index and macroeconomic variables over the period 1994 to 2011 . They found that macroeconomic variables and the stock market index are co-integrated and, hence, a long-run equilibrium relationship exists between them. It is observed 
that the stock prices positively related to the money supply and industrial production but negatively related to inflation. The exchange rate and the short-term interest rate are found to be insignificant in determining stock prices. In the Granger causality sense, macroeconomic variable causes the stock prices in the long-run but not in the short-run. There is bi-directional causality exists between industrial production and stock prices whereas, unidirectional causality from money supply to stock price, stock price to inflation and interest rates to stock prices.

Şükrüoğlu and Nalin (2014) investigate the effects of macroeconomic variables and their role in development of stock market in selected 19 European countries. They found that income, monetization ratio, liquidity ratio, saving rate and inflation effect on stock market development. Monetization ratio and inflation have negative effects while income, liquidity ratio, saving rate have positive effects on stock market development. Liquidity ratio emphasizes that the stock market liquidity help to improve stock market development. On the other side, Naceur et al. (2007) also investigated whether there is a connection between stock markets, banks and economic development. However, they could not establish any significant link between stock market development and economic growth. Sahu and Dhiman (2011) investigated the causal relationship and the direction of causality between stock market development and economic growth in India for the period from 1981 to 2006 and also found no causal relationship.

\subsection{Literature Review About Turkish Stock Market}

There are various studies about the link between macroeconomic variables and Turkish stock returns. Acikalin et al. (2008) find long-term stable relationship between Istanbul Stock Exchange (ISE) and four macroeconomic variables, namely GDP, exchange rate, interest rate, and current account balance and find unidirectional relationships between macroeconomic indicators and ISE index. Kandır (2008) by using a multiple regression model, tests the relationship between the Turkish stock portfolio returns and seven macroeconomic factors and finds that exchange rate, interest rate and world market return seem to affect all of the portfolio returns, while inflation rate is significant for only three of the twelve portfolios. On the other hand, industrial production, money supply and oil prices do not appear to have any significant effect on stock returns. Aydemir and Demirhan (2009) investigate the causal relationship between stock prices and exchange rates for Turkey and their results indicate that there is bi-directional causal relationship between exchange rate and all stock market indices. While the negative causality exists from national 100, services, financials and industrials indices to exchange rate, there is a positive causal relationship from technology indices to exchange rate. Also they found negative causal relationship from exchange rate to all stock market indices.

Uluslararası Íktisadi ve İdari İncelemeler Dergisi 
Ozbay (2009) addresses the causal relationship between stock prices and macroeconomic factors and finds that interest rate, inflation, and CD/GDP granger cause stock returns, while stock returns do granger cause money supply, exchange rate, interest rate, inflation, foreign transactions. Büyükşalvarcı and Abdioğlu (2010) examines the causal relationships by applying the long-run Granger non-causality test. Their results suggest that there is a unidirectional long-run causality from stock price to macro variables for Turkey. Savasa and Samiloglub (2010) found that money supply, IPI, interest rate, RER and FFR enhance the predictability measure of the Turkish stock market. Also they found that the changes in the US monetary policy have a significant impact on the Turkish stock market. Özlen and Ergun (2012) by using Autoregressive Distributed Lag Method (ARDL) research to identify the effects for 45 companies from 11 different sectors in Turkish BIST. Their test results indicate that exchange rate and interest rate are the most significant factors in the stock price fluctuations of the companies.

\section{Econometric Methodology and Data}

This study examines the causal relationship between selected domestic and international macroeconomic variables and the stock returns in Turkey by using monthly data covering the period from 2003:1 to 2016:12. The monthly data obtained from the Central Bank of Turkey database, International Financial Statistics (IFS), Federal Reserve Bank of St. Louis (FRED) and Yahoo finance web database. The time period is selected for many reasons. Firstly, this time period is considered as most economically and politically stable period of Turkish economy since 1970's. Economic environment was stable and applied government policies were similar. In the time period there was no domestically created financial or budget deficit crisis. Also, inflation was under control in this period. The set of macroeconomic variables are the stock market price indexes from Turkey, namely BIST100 index, BIST industrial index, BIST financial index, consumer price index, industrial production index, current account to export ratio, unemployment rate, real effective exchange rate, interest rate difference between Turkish central bank policy rate and the United States federal funds rate, World oil price index, Standard \& Poor's 500 Index.

The study utilizes the Autoregressive Distributed Lag Method (ARDL) developed by Pesaran and Shin (1999) and re-assessed by Pesaran et al. (2001) to analyze the short-run and long-run linkages between selected domestic and international macroeconomic variables and the stock returns in Turkey. The ARDL approach provides several advantages over traditional methods for evaluate of co-integration and short-run and long-run linkages. Firstly, opposite to traditional co-integration methods such as Johansen's tests (Johansen, 1991), Granger and Engle causality test (Engle and Granger, (1987)) and Vector Autoregressive (VAR) model, the ARDL can be utilized to test for a level relationship for variables that are either $I(0)$ or $I(1)$ 
as well as for mix $I(0)$ and $I(1)$ variables (Duasa 2007, Adom et al. 2012). But ARDL approach does not apply with non-stationary variables integrated of order two $I(2)$ .The possibility to combine $I(0)$ or $I(1)$ variables is great advantage as financial time series often are either $I(0)$ or $I(1)$. The advantage can be more clarified by comparing e.g. VAR with ARDL. If one would conduct a VAR approach the series are required to be stationary and if the data is non-stationary $I(1)$ one would have to take the first difference of the series and then apply VAR. However if one take the first difference of the data, long-run relations between series may disappear (Brooks, 2014). In contrast, in an ARDL framework it is not necessary to make an adjustment to the data and hence long-run relationships still remain possible to calculate. Secondly, the ARDL method integrates the short-run impact of the given variables with a long-run equilibrium using an error correction term without dropping longrun information. Accordingly one may assess the short-run and long-run relationship between the given variables simultaneously. Thirdly, unlike traditional cointegration tests, it is possible to determine different lags for each variable in the model which makes it more flexible. Lastly, most co-integration techniques are sensitive to the sample sizes while the ARDL method provides robust and consistent results for small sample sizes (Adom et al., 2012).

In order to investigate the causal relationship between selected macroeconomic variables and stock returns, the ARDL approach is used. Benefiting from the articles of Pesaran and Shin (1999) and Pesaran et al. (2001) and adjusting based equations for our current study aims, the re-assessed ARDL form is defined as follows in equation (1):

$$
\begin{aligned}
& \Delta Y_{t}=\alpha+\sum_{i=1}^{n} a_{i t} \Delta Y_{i, t-i}+\sum_{i=0}^{p} b_{i t} \Delta I N T D I F_{i, t-i}+\sum_{i=0}^{q} c_{i t} \Delta O I L_{i, t-i}+\sum_{i=0}^{s} d_{i t} \Delta R E R_{i, t-i}+\sum_{i=0}^{r} e_{i t} \Delta U N E M P_{-} S A_{i, t-i}+\sum_{i=0}^{w} f_{i y} \Delta I P I_{i, t-i} \\
& +\sum_{i=0}^{l} g_{i t} \Delta C P I_{i, t-i}+\sum_{i=0}^{k} h_{i t} \Delta S P 500_{i, t-i}+\sum_{i=0}^{z} j_{i t} \Delta C A E X_{i, t-i}+\delta_{1 i} I N T D I F_{t-i}+\delta_{2 i} O I L_{t-i}+\delta_{3 i} R E R_{t-i}+\delta_{4 i} U N E M P P_{-} S A_{t-i} \\
& +\delta_{5 i} I P I_{t-i}+\delta_{6 i} C P I_{t-i}+\delta_{7 i} S P 500_{t-i}+\delta_{8} C A E X_{t-i}+\delta_{9} Y_{t-i}+\varepsilon_{i t}
\end{aligned}
$$

Where; $\Delta$ is defined first difference of variables, $Y:$ is defined log series the index of BIST100 or the index of BISTFIN and the index of BISTIND. INTDIF :is defined interest rate difference between Turkish policy rate and the United States federal funds rate. $O I L:$ is defined World oil price index. $R E R$ : is defined real effective exchange rate.UNEMP_SA: is defined seasonally adjusted unemployment rate. $I P I$ : is defined industrial production index. $C P I:$ is defined

\section{Uluslararası İktisadi ve İdari İncelemeler Dergisi}


consumer price index. SP500:USASP500 is defined to log series of SP500 and $C A E X$ : is defined the ratio of current account balance to export. $\varepsilon$ : is defined zero mean and constant variance error term.

In order to test for the reliability of a long-run relationship between selected domestic and international macroeconomic variables and the stock returns, Eq. (1) is estimated by ordinary least squares (OLS) and then carry out an F-test for the joint significance of the coefficients of the lagged levels of the variable. Thus, the null hypothesis of no co-integration among the variables in Eq. (1) is:

$H_{0}=\delta_{1}=\delta_{2}=\delta_{3}=\delta_{4}=\delta_{5}=\delta_{6}=\delta_{7}=\delta_{8}=\delta_{9}=0$

$H_{1}: \delta_{1} \neq \delta_{2} \neq \delta_{3} \neq \delta_{4} \neq \delta_{5} \neq \delta_{6} \neq \delta_{7} \equiv \delta_{8} \neq \delta_{9} \neq 0$

By adopting ARDL approach, one can estimate the short and long-run dynamic relationships. Therefore, equation (1) can be rewritten as the error correction version of ARDL model as follow:

$$
\begin{gathered}
Y_{t}=\beta_{0}+\sum_{i=1}^{p_{1}} \beta_{1} Y_{t-i}+\sum_{i=1}^{q_{1}} \beta_{2} I N T D I F_{t-i}+\sum_{i=1}^{q_{2}} \beta_{3} O I L_{t-i}+\sum_{i=1}^{q_{3}} \beta_{4} R E R_{t-i}+\sum_{i=1}^{q_{4}} \beta_{5} U N E M P_{-} S A_{t-i}+\sum_{i=1}^{q_{5}} \beta_{6} I P I_{t-i}+\sum_{i=1}^{q_{6}} \beta_{7} C P I_{t-i} \\
+\sum_{i=1}^{q_{7}} \beta_{8} S P 500_{t-i}+\sum_{i=1}^{q_{8}} \beta_{9} C A E X_{t-i}+u_{t} \\
\Delta Y_{t}=\phi_{0}+\sum_{i=1}^{n} \phi_{1} \Delta Y_{t-i}+\sum_{i=1}^{n} \phi_{2} \Delta N T D I F_{t-i}+\sum_{i=1}^{n} \phi_{3} \Delta O I L_{t-i}+\sum_{i=1}^{n} \phi_{4} \Delta R E R_{t-i}+\sum_{i=1}^{n} \phi_{5} \Delta U N E M P_{-} S A_{t-i}+\sum_{i=1}^{n} \phi_{6} \Delta I P I_{t-i}+\sum_{i=1}^{n} \phi_{7} \Delta C P I_{t-i} \\
+\sum_{i=1}^{n} \phi_{8} \Delta S P 500_{t-i}+\sum_{i=1}^{n} \phi_{9} \Delta C A E X_{t-i}+\phi_{10} E C T_{t-1}+e_{t}
\end{gathered}
$$

where $E C T_{t-1}$ is the error correction term which has to be negative and statistically significant and represents the speed of adjustment revert to long run equilibrium following a short run shock. Then, the presence of serial correlation and heteroscedasticity in the errors of model is tested and whether it is correctly specified the functional form of the model and errors are normally distributed. Also, it is checked the stability of parameters by using cumulative (CUSUM) and cumulative sum of squares (CUSUMSQ).

\section{Empirical Results}

\subsection{The Unit Root Tests}

Table 1 below reports the results of unit root test to determine the order of integration among time series data. The Breakpoint Unit Root test has been used at 
level and first difference under the assumption of trend and intercept. The results of Breakpoint unit root test indicates that variables such as LCPI is level stationary while other variable such as LBIST100, LBISTFIN, LBISTIND, LIPI, LRER, CAEX, UNEMP and INTDIF are stationary at the first differences. The results provide a strong justification for ARDL as an estimation method to test the existence of long-run relationship among the variables.

Table 1: Breakpoint Unit Root Test Results

\begin{tabular}{|c|c|c|c|}
\hline \multirow[b]{2}{*}{ Variables } & \multicolumn{2}{|c|}{ Breakpoint Unit Root Test } & \multirow[t]{2}{*}{ Decision } \\
\hline & $\begin{array}{c}\text { Level } \\
\text { (trend and } \\
\text { intercept) }\end{array}$ & $\begin{array}{c}\text { 1st difference } \\
\text { (trend and } \\
\text { intercept) }\end{array}$ & \\
\hline LBIST100 & $\begin{array}{l}-0.7416^{*} \\
(-5.1550)\end{array}$ & $\begin{array}{c}-10.7824^{*} \\
(-5.1550)\end{array}$ & $\mathrm{I}(1)$ \\
\hline LBISTFIN & $\begin{array}{l}-1.1262^{*} \\
(-5.1550)\end{array}$ & $\begin{array}{c}-10.4999 * \\
(-5.1550) \\
\end{array}$ & $\mathrm{I}(1)$ \\
\hline LBISTIND & $\begin{array}{l}-0.5597^{*} \\
(-5.1550)\end{array}$ & $\begin{array}{c}-10.1366^{*} \\
(-5.1550)\end{array}$ & $\mathrm{I}(1)$ \\
\hline LCPI & $\begin{array}{l}-6.2526^{*} \\
(-5.1550)\end{array}$ & & $\mathrm{I}(0)$ \\
\hline LIPI & $\begin{array}{c}0.3266^{*} \\
(-5.1550)\end{array}$ & $\begin{array}{c}-15.9373^{*} \\
(-5.1550) \\
\end{array}$ & $\mathrm{I}(1)$ \\
\hline CAEX & $\begin{array}{l}-2.7645^{*} \\
(-5.1550)\end{array}$ & $\begin{array}{c}-16.9870^{*} \\
(-5.1550) \\
\end{array}$ & $\mathrm{I}(1)$ \\
\hline UNEMP & $\begin{array}{l}-0.6721^{*} \\
(-5.1550)\end{array}$ & $\begin{array}{l}-6.2812^{*} \\
(-5.1550)\end{array}$ & $I(1)$ \\
\hline LRER & $\begin{array}{l}-4.1581^{*} \\
(-5.1550) \\
\end{array}$ & $\begin{array}{l}-9.5067^{*} \\
(-5.1550) \\
\end{array}$ & $\mathrm{I}(1)$ \\
\hline INTDIF & $\begin{array}{l}-3.3176^{*} \\
(-5.1550)\end{array}$ & $\begin{array}{c}-6.3509 * \\
(-5.1550)\end{array}$ & $\mathrm{I}(1)$ \\
\hline
\end{tabular}

Note: * denotes the rejection of the unit root at $5 \%$ level of significance.

\subsection{The ARDL Bounds Test}

After determining the order of the integration of the variables, the presence of long-run relationship between selected domestic and international macroeconomic variables and the stock returns in Turkey is tested by employing the ARDL bounds testing approach. In order to test existence of such relationship, first of all optimal lag length by using Akaike information criterion (AIC) is determined. Table 2 reveals 
the results of the co-integration between dependent variables (BIST100, BISTFIN, and BISTIND) and the independent macroeconomic variables (IPI, CPI, CAEX, RER, INTDIF, S\&P500, and OILP) and also the critical values of ARDL bounds test.

Table 2: The ARDL Bounds Test

\begin{tabular}{|l|c|c|c|c|c|}
\hline Model & $\begin{array}{c}\text { Optimal lag } \\
\text { length }\end{array}$ & F-statistics & \multicolumn{2}{|c|}{$\begin{array}{c}\text { Bound } \\
\text { critical } \\
\text { value }\end{array}$} & Outcome \\
\hline & & & $\mathrm{I}(0)$ & $\mathrm{I}(1)$ & \\
\hline LBIST100 & $(2,2,0,2,0,2,1)$ & $3.9120^{*}$ & 2.27 & 3.28 & Cointegration \\
\hline LBISTFIN & $(2,2,4,2,0,2,0)$ & $6.1829^{*}$ & 2.27 & 3.28 & Cointegration \\
\hline LBISTIND & $(2,0,0,0,4,2,1)$ & $8.6363^{*}$ & 2.27 & 3.28 & Cointegration \\
\hline
\end{tabular}

Note: ${ }^{*}$ denotes the rejection of the unit root at $5 \%$ level of significance.

The results in Table 2 indicate that the calculated F-statistics reject the null hypothesis of no co-integration between variables, since calculated values of $\mathrm{F}$ statistics for LBIST100, LBISTFIN and LBISTIND (3.912, 6.182 and 8.636 respectively) are greater than I(1) bound critical value of 3.28 at the significance level of $5 \%$. Akaike information criterion (AIC) is used to determine the optimal lag length for the model. Thus, the variables are co-integrated which implies that there is a long-run relationship among them. The short-run dynamic parameters are obtained by estimating an error correction model associated with the long-run estimates. Tables 3,4 and 5 reveal the results of short-run and long-run estimates.

Table 3: Long-Run and Short-Run Estimations (LBIST100)

\begin{tabular}{|c|c|c|c|c|}
\hline \multicolumn{4}{|c|}{ Dependent variable $=$ LBIST100 } & \multirow[b]{2}{*}{$\begin{array}{l}\text { Prob. } \\
\text { values }\end{array}$} \\
\hline Variable & Coefficient & Std. Error & t-statistics & \\
\hline \multicolumn{4}{|l|}{ Short-run results } & \\
\hline D(LBIST100(-1)) & $0.1353^{*}$ & 0.0663 & 2.0391 & 0.0432 \\
\hline $\mathrm{D}(\mathrm{LCPI})$ & -0.3030 & 0.4141 & -0.7318 & 0.4654 \\
\hline $\mathrm{D}(\mathrm{LCPI}(-1))$ & -0.6583 & 0.4207 & -1.5647 & 0.1198 \\
\hline $\mathrm{D}(\mathrm{LIPI})$ & 0.0721 & 0.1923 & 0.3753 & 0.7079 \\
\hline $\mathrm{D}(\mathrm{CAEX})$ & -0.0087 & 0.0272 & -0.3230 & 0.7471 \\
\hline $\mathrm{D}(\mathrm{CAEX}(-1))$ & $-0.0478 * *$ & 0.0255 & -1.8715 & 0.0632 \\
\hline D(UNEMP_SA) & 0.0005 & 0.0143 & 0.0385 & 0.9693 \\
\hline $\mathrm{D}$ (LRER) & $1.1539 *$ & 0.1264 & 9.1287 & 0.0000 \\
\hline $\mathrm{D}(\operatorname{LRER}(-1))$ & -0.2296 & 0.1567 & -1.4650 & 0.1450 \\
\hline D(INTDIF) & $-0.0132 *$ & 0.0041 & -3.1777 & 0.0018 \\
\hline D(LSP500) & $0.5319 *$ & 0.0962 & 5.5244 & 0.0000 \\
\hline
\end{tabular}




\begin{tabular}{|c|c|c|c|c|}
\hline $\mathrm{D}$ (LOILP) & $0.0771 * *$ & 0.0409 & 1.8868 & 0.0611 \\
\hline CointEq(-1) & -0.1676 & 0.0271 & -6.1791 & 0.0000 \\
\hline \multicolumn{5}{|l|}{ Long-run results } \\
\hline LCPI & 0.2246 & 0.4032 & 0.5570 & 0.5784 \\
\hline LIPI & 0.4480 & 1.0532 & 0.4253 & 0.6712 \\
\hline CAEX & 0.2200 & 0.2147 & 1.0244 & 0.3073 \\
\hline UNEMP_SA & 0.0221 & 0.0326 & 0.6787 & 0.4983 \\
\hline LRER & $0.8520 *$ & 0.4463 & 1.9087 & 0.0582 \\
\hline INTDIF & $-0.0366^{*}$ & 0.0074 & -4.9034 & 0.0000 \\
\hline LSP500 & $0.6836 *$ & 0.2369 & 2.8847 & 0.0045 \\
\hline LOILP & 0.0669 & 0.0923 & 0.7254 & 0.4694 \\
\hline $\mathrm{C}$ & -1.1340 & 2.7700 & -0.4093 & 0.6828 \\
\hline Test & \multicolumn{2}{|c|}{ Test Statistics } & Probability & \\
\hline Normality & \multicolumn{2}{|c|}{10.2519} & 0.0059 & \\
\hline Functional form & \multicolumn{2}{|c|}{7.1646} & 0.0083 & \\
\hline Heteroscedasticity & \multicolumn{2}{|c|}{$23.6720 * * *$} & 0.1286 & \\
\hline Serial correlation & \multicolumn{2}{|c|}{15.2893} & 0.1696 & \\
\hline CUSUM & \multicolumn{3}{|c|}{ Stable } & \\
\hline CUSUMSQ & \multicolumn{3}{|c|}{ Stable } & \\
\hline
\end{tabular}

Note:*denotes the rejection of null hypothesis at $5 \%$ level of significance.

$* *$ denotes the rejection of null hypothesis at $10 \%$ level of significance

*** denotes Breusch-Pagan-Godfrey test results.

Table 3 shows short-run and long-run relations between BIST100 and selected macroeconomic variables. Turkish stock returns represented by BIST100 is affected from changes in BIST100 with lag, current account to export ratio with lag, real effective exchange rate, interest rate difference between Turkish central bank policy rate and the United States federal funds rate, S\&P500 and World Oil Price Index in the short-run. The estimated coefficient of RER, S\&P500, OILP are statistically significant and have a positive sign. But, the estimated coefficient of BIST100 with lag, CAEX with lag, INTDIF are statistically significant and have a negative sign. In the long-run, main effect is coming from changes in real effective exchange rate, S\&P500 and World Oil Price Index. The estimated coefficient of RER, S\&P500 are statistically significant and positive. But, the estimated coefficient of INTDIF is statistically significant and negative.

The negative and statistically significant estimate of the CointEq(-1) coefficient, which is another way of representing $E C T_{t-1}$, provides another evidence for established long run relationship between selected domestic and international 
macroeconomic variables and the stock returns. According to estimated value of CointEq(-1) coefficient, which is a speed of adjustment, changes in BIST100 are corrected by $16 \%$ in each month. According to the $p$-values of chi-square tests which test the null hypothesis of normal distribution of errors, correctly specified functional form, no serial correlation and homoscedastic errors reject the null hypothesis implying that well specification of the models, normally distributed errors, but fail to reject the null hypothesis with no serial correlation and homoscedastic variances. Figure 1 and 2 in the Appendix plots of cumulative sum of recursive residual (CUSUM) and cumulative sum of squares of recursive residual (CUSUMQ) of the model statistics are well within the critical bounds, the coefficients of the error-correction model are stable indicating that the coefficients follow a stable pattern during the estimation period.

Table 4: Long-Run and Short-Run Estimations (LBISTFIN)

\begin{tabular}{|c|c|c|c|c|}
\hline \multicolumn{4}{|c|}{ Dependent variable = LBISTFIN } & \multirow[b]{2}{*}{$\begin{array}{c}\text { Prob. } \\
\text { values }\end{array}$} \\
\hline Variable & Coefficient & Std. Error & t-statistics & \\
\hline \multicolumn{4}{|c|}{ Short-run Results } & \\
\hline $\mathrm{D}($ LBISTFIN(-1)) & $0.1529 *$ & 0.0636 & 2.4048 & 0.0175 \\
\hline $\mathrm{D}(\mathrm{LCPI})$ & -0.5565 & 0.4852 & -1.1467 & 0.2534 \\
\hline $\mathrm{D}(\mathrm{LCPI}(-1))$ & $-1.1530 *$ & 0.4922 & -2.3421 & 0.0206 \\
\hline $\mathrm{D}(\mathrm{LIPI})$ & -0.0255 & 0.2219 & -0.1152 & 0.9084 \\
\hline $\mathrm{D}(\mathrm{LIPI}(-1))$ & 0.0614 & 0.2287 & 0.2686 & 0.7886 \\
\hline $\mathrm{D}(\mathrm{LIPI}(-2))$ & 0.3552 & 0.2219 & 1.6006 & 0.1117 \\
\hline $\mathrm{D}(\mathrm{LIPI}(-3))$ & $0.4563^{*}$ & 0.2197 & 2.0763 & 0.0397 \\
\hline $\mathrm{D}(\mathrm{CAEX})$ & 0.0039 & 0.0311 & 0.1256 & 0.9002 \\
\hline $\mathrm{D}(\mathrm{CAEX}(-1))$ & $-0.0681^{*}$ & 0.0297 & -2.2916 & 0.0234 \\
\hline D(UNEMP_SA) & -0.0006 & 0.0174 & -0.0380 & 0.9697 \\
\hline $\mathrm{D}$ (LRER) & $1.4016^{*}$ & 0.1430 & 9.7969 & 0.0000 \\
\hline $\mathrm{D}(\operatorname{LRER}(-1))$ & $-0.3215^{* *}$ & 0.1737 & -1.8511 & 0.0662 \\
\hline D(INTDIF) & $-0.0131^{*}$ & 0.0047 & -2.7761 & 0.0062 \\
\hline $\mathrm{D}($ LSP500) & $0.6028^{*}$ & 0.1118 & 5.3905 & 0.0000 \\
\hline $\mathrm{D}($ LOILP) & 0.0705 & 0.0471 & 1.4983 & 0.1362 \\
\hline CointEq(-1) & -0.2157 & 0.0300 & -7.1767 & 0.0000 \\
\hline \multicolumn{5}{|c|}{ Long-run Results } \\
\hline LCPI & 0.4219 & 0.4280 & 0.9856 & 0.3260 \\
\hline LIPI & -0.4272 & 1.0940 & -0.3905 & 0.6967 \\
\hline CAEX & $0.3917^{*}$ & 0.1869 & 2.0961 & 0.0378 \\
\hline UNEMP_SA & -0.0074 & 0.0309 & -0.2409 & 0.8099 \\
\hline LRER & $1.6065^{*}$ & 0.3804 & 4.2229 & 0.0000 \\
\hline
\end{tabular}




\begin{tabular}{|c|c|c|c|c|}
\hline INTDIF & $-0.0469 *$ & 0.0059 & -7.8579 & 0.0000 \\
\hline LSP500 & $0.7446^{*}$ & 0.2074 & 3.5896 & 0.0005 \\
\hline LOILP & 0.0064 & 0.0758 & 0.0847 & 0.9326 \\
\hline $\mathrm{C}$ & -0.7542 & 2.4659 & -0.3058 & 0.7601 \\
\hline Test & \multicolumn{2}{|c|}{ Test Statistics } & Probability & \\
\hline Normality & \multicolumn{2}{|c|}{3.3982} & 0.1828 & \\
\hline Functional form & \multicolumn{2}{|c|}{1.5923} & 0.2091 & \\
\hline Heteroscedasticity & \multicolumn{2}{|c|}{$21.6399 * * *$} & 0.3604 & \\
\hline Serial correlation & \multicolumn{2}{|c|}{15.6997} & 0.1526 & \\
\hline CUSUM & \multicolumn{3}{|c|}{ Stable } & \\
\hline CUSUMSQ & \multicolumn{3}{|c|}{ Stable } & \\
\hline
\end{tabular}

Note:*denotes the rejection of null hypothesis at $5 \%$ level of significance.

$* *$ denotes the rejection of null hypothesis at $10 \%$ level of significance.

*** denotes Breusch-Pagan-Godfrey test results.

Table 4 shows short-run and long-run relations between BISTFIN and selected macroeconomic variables. The BIST financial index is affected from changes in BISTFIN with lag, Turkish consumer price index with lag, industrial production index with lag, current account to export ratio with lag, real effective exchange rate and its lag, interest rate difference, S\&P500 and World Oil Price Index in the short-run. The estimated coefficient of BISTFIN with lag, IPI with lag, RER, S\&P500 are statistically significant and have a positive sign. But, the estimated coefficient of INTDIF,CPI with lag, CAEX with lag, RER with lag are statistically significant and have a negative sign. In the long-run, the main effect is coming from the changes of current account to export ratio, real effective exchange rate, interest rate difference and S\&P500. The estimated coefficient of CAEX, RER, S\&P500 are statistically significant and positive. But, the estimated coefficient of INTDIF is statistically significant and negative.

The negative and statistically significant estimate of the CointEq(-1) coefficient provides another evidence for established long run relationship between selected domestic and international macroeconomic variables and the stock returns. According to estimated value of CointEq(-1) coefficient, which is a speed of adjustment, changes in BISTFIN are corrected by $21 \%$ in each month. According to the $p$-values of chi-square tests which test the null hypothesis of normal distribution of errors, correctly specified functional form, no serial correlation and homoscedastic errors fail to reject the null hypothesis implying that well specification of the models, normally distributed errors with no serial correlation and homoscedastic variances. Figure 3 and 4 in the appendix plots of cumulative sum of recursive residual (CUSUM) and cumulative sum of squares of recursive residual

\section{Uluslararası İktisadi ve İdari İncelemeler Dergisi}


(CUSUMQ) of the model statistics are well within the critical bounds, the coefficients of the error-correction model are stable indicating that the coefficients follow a stable pattern during the estimation period.

Table 5 shows short-run and long-run relations between BISTIND and selected macroeconomic variables. The BIST industrial index is affected from changes in BISTIND with lag, industrial production index, real effective exchange rate and its lag, interest rate difference, S\&P500 and World Oil Price Index in the short-run. In the short-run, the estimated coefficient of BISTIND with lag, RER, S\&P500, IPI, OILP are statistically significant and have a positive impact on BISTIND. But, the estimated coefficient of RER with lag, INTDIF are statistically significant and have a negative impact on BISTIND. But in the long-run, the main effect is coming from changes in Turkish consumer price index, industrial production index, real effective exchange rate, interest rate difference and S\&P500. In long-run, the estimated coefficient of CPI, IPI, RER, S\&P500 are statistically significant and have a positive impact on BISTIND. But, the estimated coefficient of INTDIF is statistically significant and has a negative impact on BISTIND.

The negative and statistically significant estimate of the CointEq(-1) coefficient provides another evidence for established long run relationship between selected domestic and international macroeconomic variables and the stock returns. According to estimated value of CointEq(-1) coefficient, which is a speed of adjustment, changes in BISTIND are corrected by $33 \%$ in each month.

Table 5: Long-Run and Short-Run Estimations (LBISTIND)

\begin{tabular}{|c|c|c|c|c|}
\hline \multicolumn{2}{|l|}{ Dependent variable $=$ LBISTIND } & \\
\hline Variable & coefficient & Std. Error & t-statistic & $\begin{array}{c}\text { Prob. } \\
\text { values }\end{array}$ \\
\hline Short-run results & \multicolumn{4}{l|}{} \\
\hline D(LBISTIND(-1)) & $0.2845^{*}$ & 0.0645 & 4.409791 & 0.0000 \\
\hline D(LCPI) & 0.1029 & 0.2934 & 0.350653 & 0.7264 \\
\hline D(LIPI) & $0.3531^{*}$ & 0.1651 & 2.138526 & 0.0341 \\
\hline D(CAEX) & -0.0058 & 0.0215 & -0.270375 & 0.7873 \\
\hline D(UNEMP_SA) & -0.0050 & 0.0135 & -0.371500 & 0.7108 \\
\hline D(UNEMP_SA(-1)) & -0.0188 & 0.0139 & -1.349909 & 0.1791 \\
\hline D(UNEMP_SA(-2)) & -0.0117 & 0.0131 & -0.893287 & 0.3732 \\
\hline D(UNEMP_SA(-3)) & -0.0162 & 0.0130 & -1.245074 & 0.2151 \\
\hline D(LRER) & $0.9122^{*}$ & 0.1054 & 8.651010 & 0.0000 \\
\hline D(LRER(-1)) & $-0.2461^{*}$ & 0.1273 & -1.932303 & 0.0553 \\
\hline D(INTDIF) & $-0.0178^{*}$ & 0.0036 & -4.924918 & 0.0000 \\
\hline D(LSP500) & $0.4093^{*}$ & 0.0840 & 4.872058 & 0.0000 \\
\hline
\end{tabular}




\begin{tabular}{|c|c|c|c|c|}
\hline $\mathrm{D}$ (LOILP) & $0.1342^{*}$ & 0.0353 & 3.797428 & 0.0002 \\
\hline CointEq(-1) & -0.3385 & 0.0468 & -7.228646 & 0.0000 \\
\hline \multicolumn{5}{|l|}{ Long-run results } \\
\hline LCPI & $0.4064^{*}$ & 0.1599 & 2.5414 & 0.0121 \\
\hline LIPI & $1.2343^{*}$ & 0.3931 & 3.1392 & 0.0020 \\
\hline CAEX & -0.0515 & 0.0561 & -0.9168 & 0.3607 \\
\hline UNEMP_SA & 0.0135 & 0.0126 & 1.0729 & 0.2851 \\
\hline LRER & $0.5156^{*}$ & 0.1691 & 3.0489 & 0.0027 \\
\hline INTDIF & $-0.0206^{*}$ & 0.0028 & -7.1897 & 0.0000 \\
\hline LSP500 & $0.5918^{*}$ & 0.0876 & 6.7517 & 0.0000 \\
\hline LOILP & 0.0258 & 0.0346 & 0.7463 & 0.4566 \\
\hline $\mathrm{C}$ & -3.6189 & 0.9638 & -3.7548 & 0.0002 \\
\hline Test & \multicolumn{2}{|c|}{ Test statistic } & Probability & \\
\hline Normality & \multicolumn{2}{|c|}{0.4361} & 0.8040 & \\
\hline Functional form & \multicolumn{2}{|c|}{1.1664} & 0.2819 & \\
\hline Heteroscedasticity & \multicolumn{2}{|c|}{$15.3780 * * *$} & 0.5683 & \\
\hline Serial correlation & \multicolumn{2}{|c|}{15.9079} & 0.1446 & \\
\hline CUSUM & \multicolumn{3}{|c|}{ Stable } & \\
\hline CUSUMSQ & \multicolumn{3}{|c|}{ Stable } & \\
\hline
\end{tabular}

Note: ${ }^{*}$ denotes the rejection of null hypothesis at $5 \%$ level of significance.

$* *$ denotes the rejection of null hypothesis at $10 \%$ level of significance.

*** denotes Breusch-Pagan-Godfrey test results.

According to the $p$-values of chi-square tests which test the null hypothesis of normal distribution of errors, correctly specified functional form, no serial correlation and homoscedastic errors fail to reject the null hypothesis implying that well specification of the models, normally distributed errors with no serial correlation and homoscedastic variances. Figure 5 and 6 in the appendix plots of cumulative sum of recursive residual (CUSUM) and cumulative sum of squares of recursive residual (CUSUMQ) of the model statistics are well within the critical bounds, the coefficients of the error-correction model are stable indicating that the coefficients follow a stable pattern during the estimation period.

\section{Concluding Remarks and Policy Implications}

This paper examines the short and long run causal relationship between key domestic and international macroeconomic variables and stock market prices in Turkey and finds that main determinants of Turkish stock returns are the changes in industrial production index, consumer price index, current account to export ratio, real exchange rate, S\&P500, World Oil Price Index and the interest rate difference in 
the long-run. The signs of industrial production index, consumer price index, current account to export ratio, real effective exchange rate, S\&P500 and World Oil Price Index are positive and the sign of the interest difference between Turkish central bank policy rate and the FFR is negative. The test results show that Turkish unemployment rate does not have any short and long-run effect on Turkish stock returns.

Based on the empirical results of this study, positive relationship between IPI and stock returns is expected and implies that increase in economic activity which is represented by an increase in IPI causes stock prices and hence returns to increase. The positive relationship between inflation and stock returns indicate that the Keynesian approach is correct and the link comes from the positive inflationeconomic activity relationship and hence inflation to stock returns. The positive relationship between CAEX ratio to stock returns indicate that in Turkey economic activity requires the use of foreign inputs such as the machinery and oil and increase in current account deficit causes stock returns to increase through the increase in economic activity. The positive signs of S\&P500 and OILP indicates that increase in global economic activity causes Turkish stock returns to increase. The negative effect of INTDIF is expected and shows that increase in interest rate or interest rate difference causes the cost of borrowing to increase and hence reduces the current and future profitability of firms to decrease. The test results also shows positive relationship between RER and the stock returns in the long run. Since Turkey has an intermediate goods depended economy, overvaluation of lira makes imports cheaper and reduces input costs in production. As a result, overvaluation of lira causes firms' future profitability (See this effect in Özer (2015)). This result is also possible if the Turkish Lira is overvalued since it represents the strength of the economic activity and competitiveness of the Turkish products and hence leads stock returns to increase.

Based on the empirical test results, the investors of Turkish stock markets should pay attention to both the domestic and international macroeconomic developments. Developments in Turkish industrial production index, consumer price index, current account to export ratio, real exchange rate, S\&P500, World Oil Price Index and the domestic and the USA interest rates affect the Turkish stock prices/returns in short and long-run. 


\section{References}

Abdalla, A. and Murinde, V. (1997) Exchange rate and stock price interactions in emerging financial markets: evidence on India, Korea, Pakistan and the Philippines, Applied Financial Economics, Vol. 7, Issue 1, pp. 25-35.

Abdullah, D.A. and Hayworth, S.C. (1993) Macroeconomics of Stock Price Fluctuations, Quarterly Journal of Business and Economics, 32, pp.50-67.

Abugri, B. A. (2008) Empirical relationship between macroeconomic volatility and stock returns: Evidence from Latin American markets, International Review of Financial Analysis, Volume 17, Issue 2, pp.396-410.

Acikalin, S., Aktas, R., and Unal,S. (2008), Relationships Between Stock Markets And Macroeconomic Variables: An Empirical Analysis of The Istanbul Stock Exchange, Investment Management and Financial Innovations, Volume 5, Issue 1, pp. 8-16.

Adom, P.K., Bekoe,W. and Akoena, S.K.K. (2012) Modelling Aggregate Domestic Electricity Demand In Ghana: An Autoregressive Distributed Lag Bounds Cointegration Approach, Energy Policy 42, pp.530-537.

Apergis, NT. (1998) Stock Market Volatility and Deviations From Macroeconomic Fundamentals: Evidence From GARCH And GARCH-X Models, Kredit und Kapital, Heft 3: pp.400-412.

Aydemir, O. and Demirhan, E. (2009) The Relationship Between Stock Prices And Exchange Rates Evidence From Turkey, International Research Journal of Finance and Economics, Issue 23, pp.207-215.

Büyükşalvarcı, A. and Abdioğlu, H. (2010). Corporate Governance, Financial Ratios and Stock Returns: An Empirical Analysis of İstanbul Stock Exchange (ISE), International Research Journal of Finance and Economics, Issue 57, pp.7081.

Brooks, C. (2014) "Introductory Econometrics for Finance", Cambridge University Press, 3rd Edition, June 2014.

Chen, N.-F., Roll, R. and Ross, S. A. (1986) Economics Forces And The Stock Market, Journal of Business, Vol.59,No.3. pp.383-403.

Choi, J.J. (1995) The Japanese And US Stock Prices: A Comparative Fundamental Analysis, Japan and the World Economy, Vol. 7, Issue 3, pp.347-360

Uluslararası İktisadi ve İdari İncelemeler Dergisi 
Dhakal, D., Kandil, M. and Sharma, S.C. (1993) Causality Between The Money Supply and Share Prices: A VAR Investigation, Quarterly Journal of Business and Economics, 32, p.52-74.

Duasa, J. (2007) Determinants of Malaysian Trade Balance: An ARDL Bound Testing Approach, Global Economic Review Perspectives on East Asian Economies and Industries, Volume 36, Issue 1, pp.89-102.

Engle, Robert F. and Granger, C. W. J. (1987) Co-Integration and Error Correction: Representation, Estimation, and Testing, Econometrica, Vol. 55, No. 2., pp. 251-276.

Fama, E.F. (1981) Stock Returns, Real Activity, Inflation, and Money, The American Economic Review, Vol. 71, No. 4, pp. 545-565

Fama, E. F. (1990) Stock Returns, Expected Returns, And Real Activity, The Journal of Finance, Volume 45, Isuue 4, pp. 1089-108.

Gallinger, George W.(1994) Causality Tests of The Real Stock Return-Real Activity Hypothesis, Journal of Financial Research, Vol.17,No.2, pp.271-288.

Geske, R. and Roll, R. (1983) The Fiscal and Monetary Linkage Between Stock Returns and Inflation, The Journal of Finance, Vol. 38, No. 1, pp. 1-33

Gjerde, $\varnothing$. and Sættem, F. (1999) Causal Relations Among Stock Returns And Macroeconomic Variables In A Small, Open Economy, Journal of International Financial Markets, Institutions and Money, Vol. 9, Issue 1, pp.61-74.

Gultekin, N. B. (1983) Stock Market Returns and Inflation: Evidence from Other Countries, The Journal of Finance, Vol. 38, No. 1, pp. 49-65

Humpe, A. and Macmillan, P. (2009) Can Macroeconomic Variables Explain LongTerm Stock Market Movements? A Comparison of the US and Japan, Applied Financial Economics, 2009, Vol. 19, Issue 2, pp.111-119.

Johansen,S. (1991) Estimation and Hypothesis Testing of Cointegration Vectors in Gaussian Vector Autoregressive Models, Econometrica, Vol. 59, No. 6, pp. 1551-1580

Kandir, S.Y. (2008) Macroeconomic Variables, Firm Characteristics and Stock Returns: Evidence from Turkey, International Research Journal of Finance and Economics, Issue 16, pp.35-45.

Kumar, N.P.and Padhi, P. (2012) The impact of Macroeconomic Fundamentals on Stock Prices revisited: An Evidence from Indian Data, Munich Personal RePEC Archive MPRA Paper No. 38980, pp.1-24 
Kwon, C.S. and Shin, T.S. (1999) Cointegration And Causality Between Macroeconomic Variables And Stock Market Returns, Global Finance Journal, Vol. 10, Issue 1, pp.71-81.

Levine, R. and Zervos S. (1998) Stock Markets, Banks, and Economic Growth, The American Economic Review, Vol. 88, No. 3., pp. 537-558.

Mahdavi S. and Sohrabian A. (1991) The Link between the Rate of Growth of Stock Prices and the Rate of Growth of GNP in the United States: A Granger Causality Test, The American Economist, Vol. 35, No. 2 (Fall, 1991), pp. 4148

Mukherjee, T.K. and Naka, A. (1995) Dynamic Relations between Macroeconomic Variables and the Japanese Stock Market: An Application of a Vector Error Correction Model, Journal of Financial Research, Vol. 18, Issue 2, pp.223-37

Naceur, S.B., Ghazouani, S. and Omran,M. (2007) The Determinants Of Stock Market Development In The Middle-Eastern And North African Region, Managerial Finance, Vol. 33 Issue: 7, pp.477-489.

Nasseh, A.and Strauss, J. (2000) Stock Prices And Domestic And International Macroeconomic Activity: A Cointegration Approach, The Quarterly Review of Economics and Finance, Volume 40, Issue 2, pp.229-245.

Ozbay, E. (2009) The Relationship Between Stock Returns And Macroeconomic Factors: Evidence From Turkey, University of Exeter, Dissertation of Master of Science, Sept. 2009.

Özer, Mustafa (2015) Can Turkey be a Good Example for the Balkan Nations? The Story of Illusion of Well-Being, in Editon of Xavier Richet, Hasan Hanic and Zoran Grubisic, New Economic Policy Reforms, Belgrade Banking Academy, Belgrade, Serbia, pp. 15-58

Özlen, Ş. and Ergun, U. (2012) Macroeconomic Factors and Stock Returns, International Journal of Academic Research in Business and Social Sciences, Vol. 2, No. 9, pp. 315-343.

Pesaran, H. and Shin, Y. (1999) An Autoregressive Distributed Lag Modelling Approach to Cointegration Analysis, In S. Strom (eds.) Econometrics and Economic Theory in the $20^{\text {th }}$ Century: The Ragnar Frisch Centennial Symposium Cambridge University Press.

Pesaran, M. H., Shin, Y. and Smith, R. J. (2001) Bounds Testing Approaches to the Analysis of Level Relationships, Journal of Applied Econometrics, Vol. 16, Issue 3, pp. 289-326.

Uluslararası Íktisadi ve İdari İncelemeler Dergisi 
Pradhan, R. P., Arvin, M. B., Samadhan, B., and Taneja, S. (2013). The Impact Of Stock Market Development On Inflation And Economic Growth Of 16 Asian Countries: A Panel VAR Approach, Applied Econometrics and International Development, Vol.13(1), pp. 203-220.

Ratanapakorna, O. and Sharmab, S. C. (2007) Dynamic Analysis Between The US Stock Returns And The Macroeconomic Variables, Applied Financial Economics, Volume 17, Issue 5, pp. 369-377.

Rousseau, P.L. and Wachtel, P. (2000) Equity Markets And Growth: Cross-Country Evidence On Timing And Outcomes, 1980-1995, Journal of Banking \& Finance, Volume 24, Issue 12, pp.1933-195.

Sahu, N. C. and Dhiman, D. H. (2011) Correlation and Causality Between Stock Market and Macro Economic Variables In India: An Empirical Study, International Proceedings of Economics Development and Research, Vol. 3, pp. 281-284.

Savasa, B. and Samiloglub, F. (2010) The Impact Of Macroeconomic Variables on Stock Returns In Turkey: An ARDL Bounds Testing Approach, Afyon Kocatepe Üniversitesi, i.i.B.F. Dergisi, Vol.XII, No. I, pp.111-122.

Schwert G. W. (1981) The Adjustment of Stock Prices to Information About Inflation, The Journal of Finance, Vol.36, Issue 1, pp. 15-29.

Schwert G. W. (1990) Stock Returns and Real Activity: A Century of Evidence, The Journal of Finance, Vol. XLV, No.4, pp. 1237-1257.

Shahbaz, M., Ahmed, N. and Ali, L. (2008) Stock Market Development and Economic Growth: ARDL Causality in Pakistan, International Research Journal of Finance and Economics, Issue 14, pp. 182-195.

Singh, T., Mehta,S. and Varsha, M. S. (2011) Macroeconomic factors and stock returns: Evidence from Taiwan, Journal of Economics and International Finance, Vol. 2(4), pp.217-227.

Şükrüoğlu, D. and Nalin, H.T. (2014) The Macroeconomic Determinants of Stock Market Development in Selected European Countries: Dynamic Panel Data Analysis, International Journal of Economics and Finance; Vol. 6, No. 3, pp.64-71.

Tripathy, N., (2011) Causal Relationship between Macro Economic Indicators and Stock Market in India, Asian Journal of Finance \& Accounting, Vol. 3, No. 1: E13, pp.208-226. 
Vazakidis, A. and Adamopoulos, A. (2009) Stock Market Development and Economic Growth, American Journal of Applied Sciences, Volume 6, Issue 11, pp.19321940.

Yartey, A.C. (2010) The Institutional And Macroeconomic Determinants Of Stock Market Development In Emerging Economies, Applied Financial Economics, Volume 20, Issue 21, pp. 1615-1625.

\section{Appendix}

Figure 1: Plot of Cumulative Sum of Recursive for LBIST100

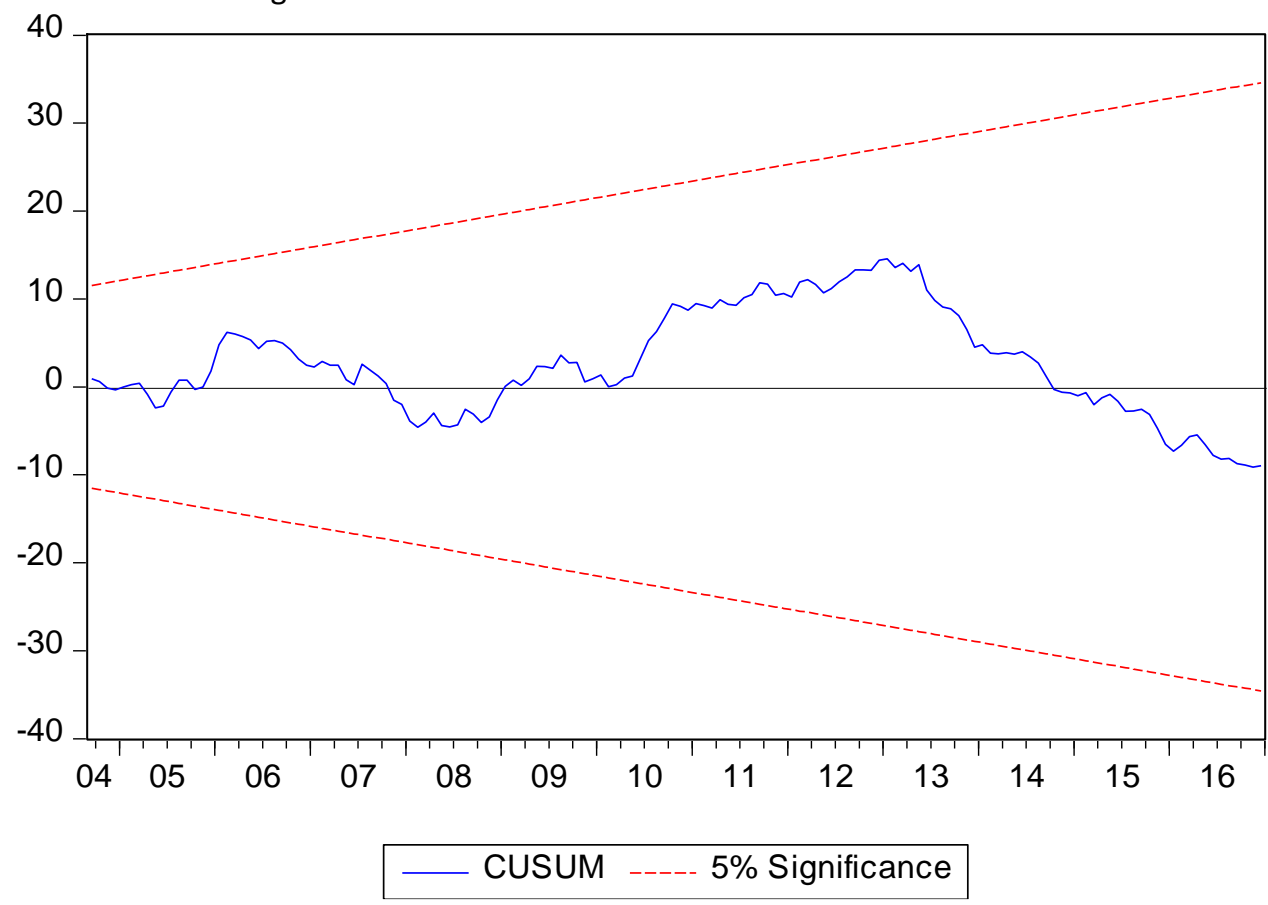

Uluslararası İktisadi ve İdari İncelemeler Dergisi 


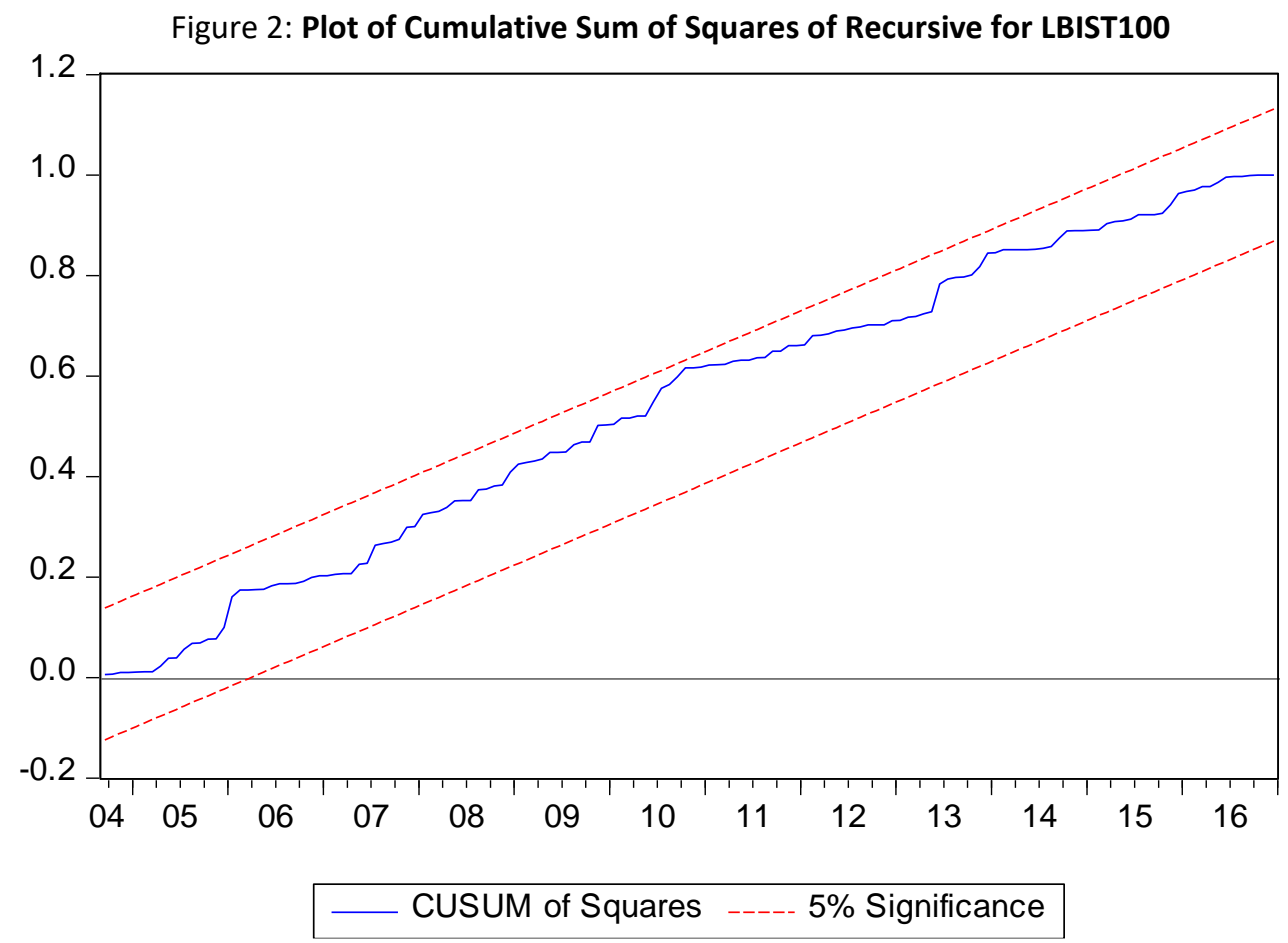




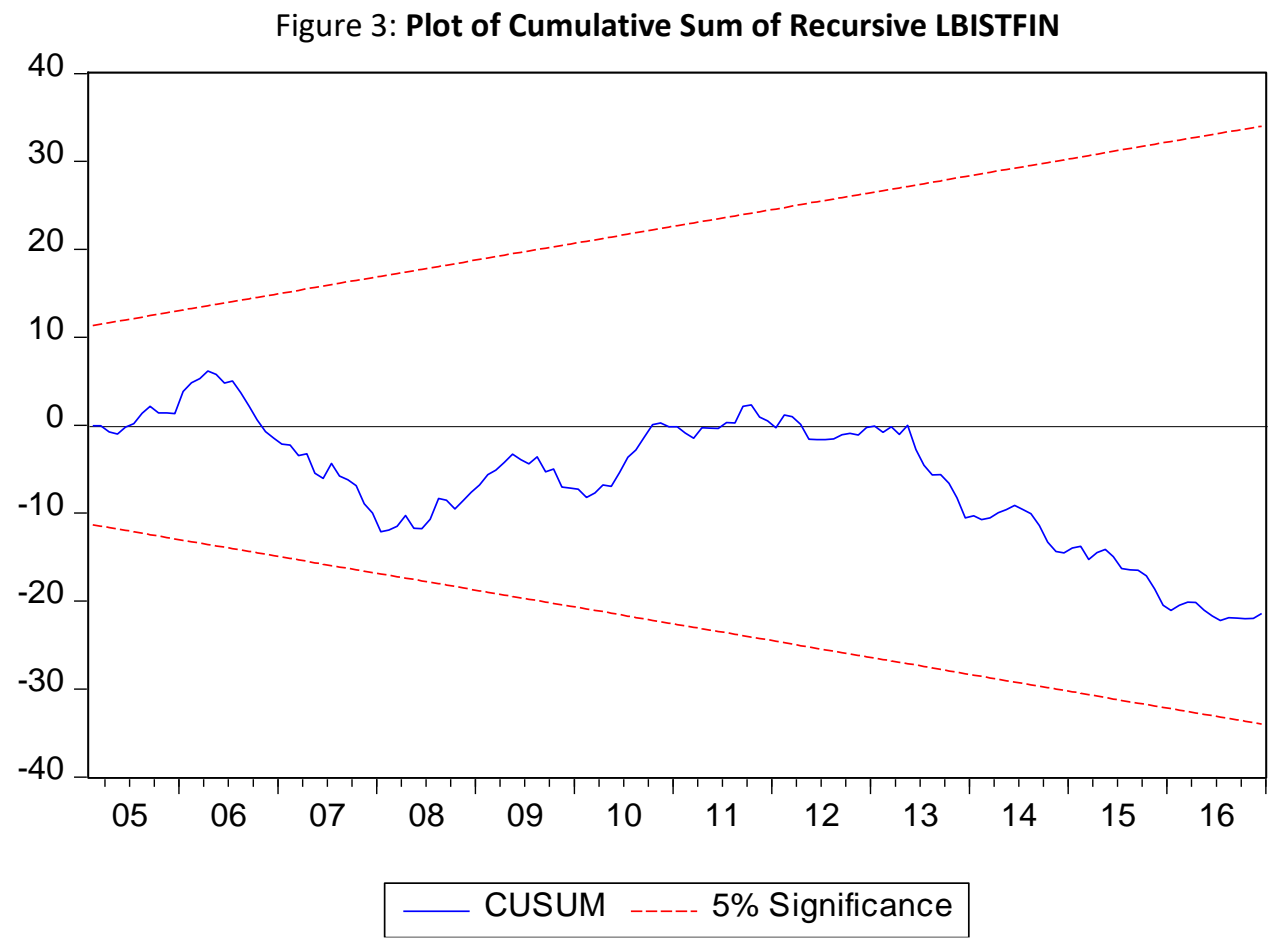




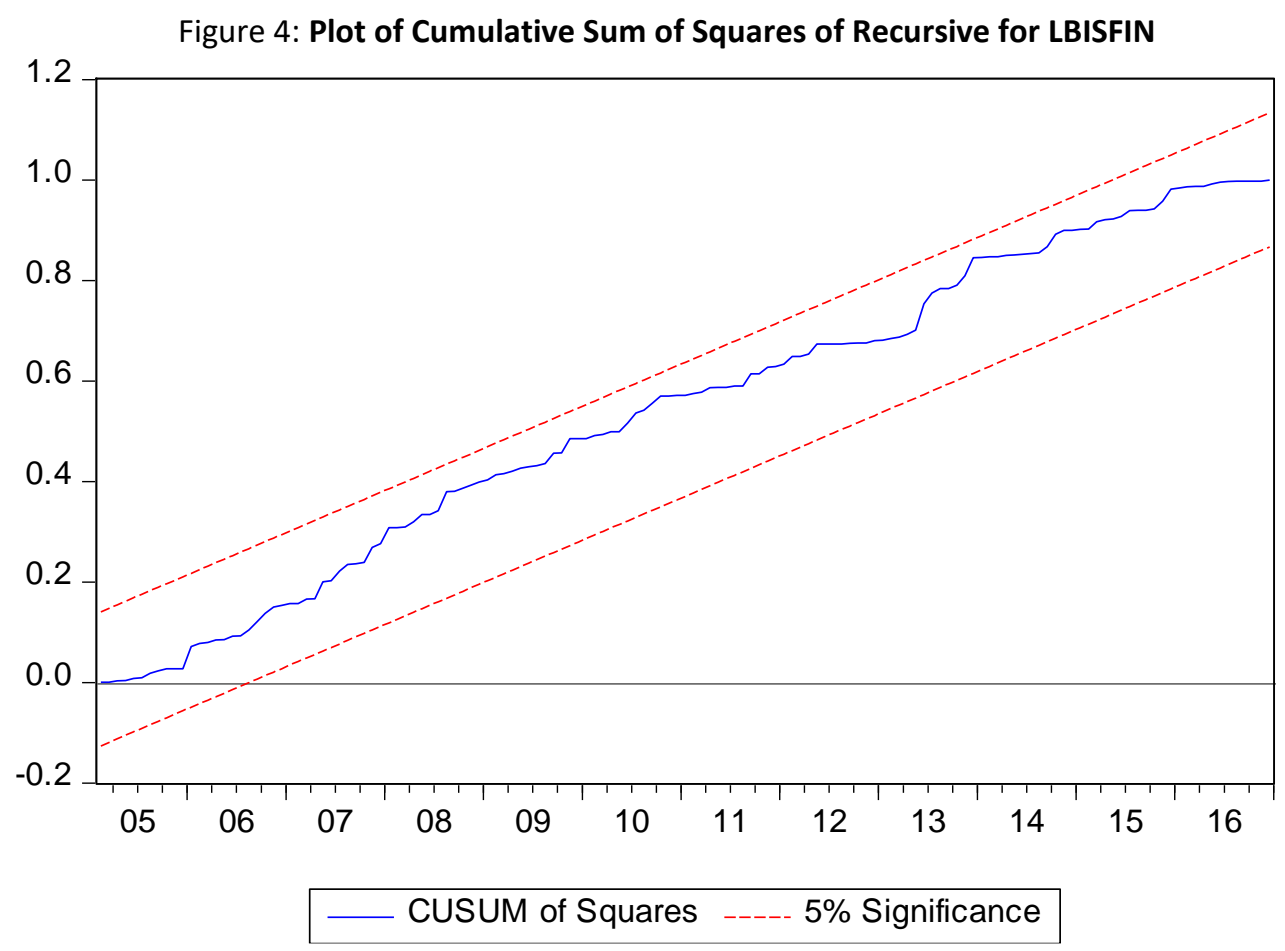




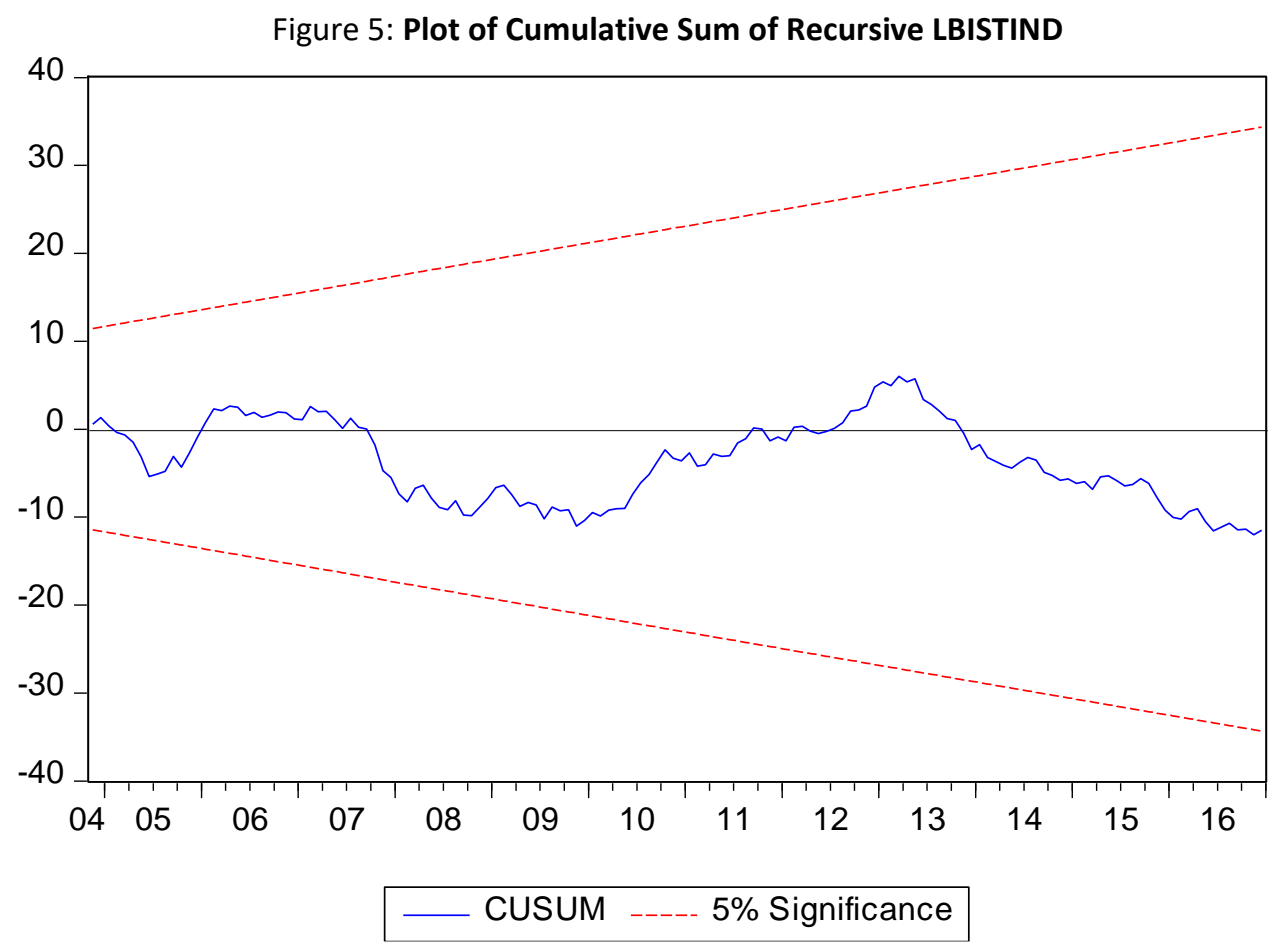

Uluslararası İktisadi ve İdari İncelemeler Dergisi 


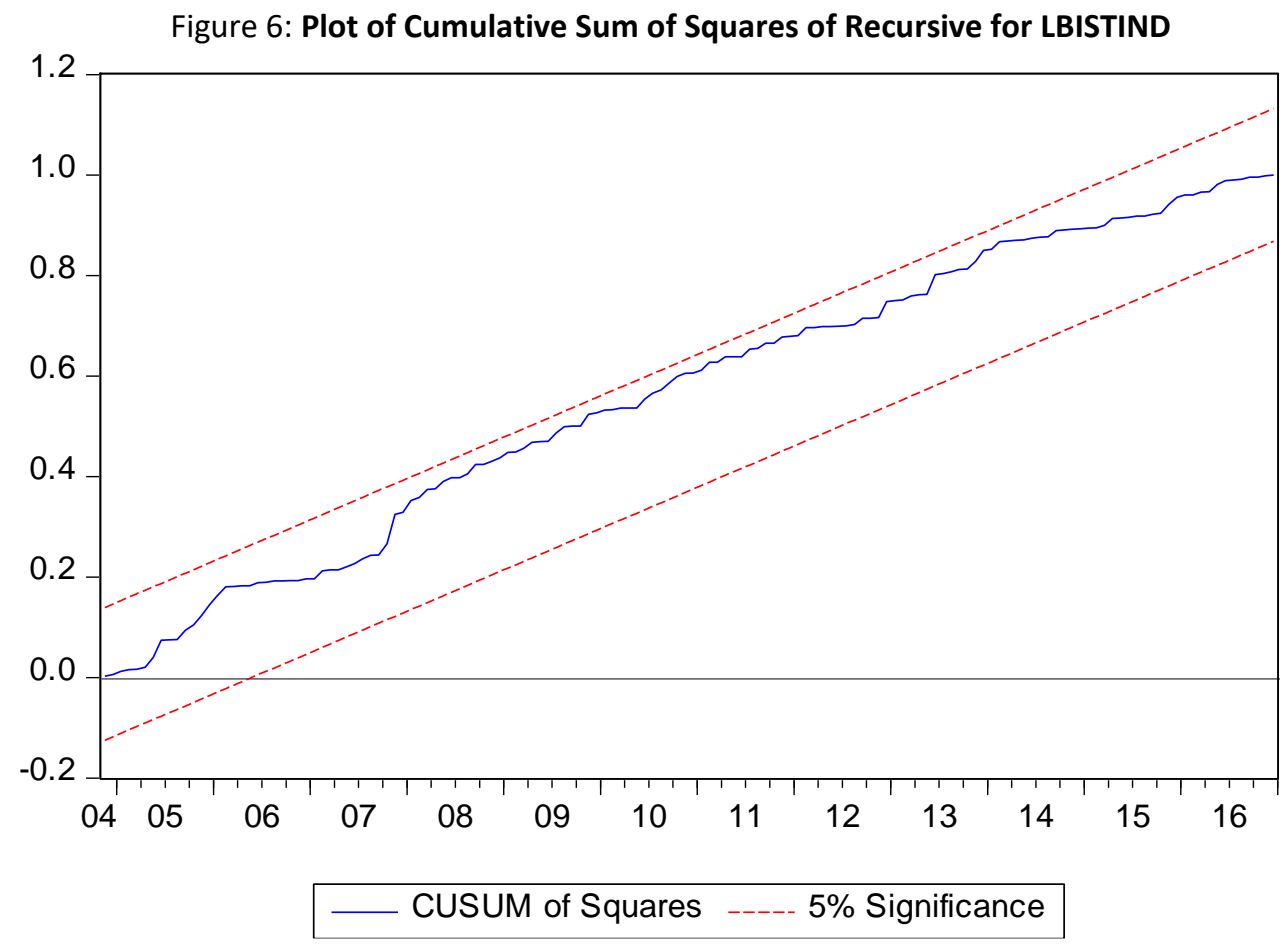

